KOŚCIÓŁ I PRAWO 10(23) 2021, nr 2, s. 137-146

DOI: https://doi.org/10.18290/kip21102.9

\author{
Michał Poniatowski
}

\title{
ZAKŁADANIE SPÓŁDZIELNI SOCJALNYCH PRZEZ KOŚCIELNE OSOBY PRAWNE
}

\section{WPROWADZENIE}

Jednym z celów działalności kościelnych osób prawnych jest prowadzenie $\mathrm{w}$ odpowiednim stopniu działalności charytatywnej. W ten sposób - równolegle do celów o charakterze religijnym - zachowana jest m.in. troska o dobro wspólne i dobro człowieka, która stanowi także cel działania wielu organizacji pozarządowych. Kościelne osoby prawne mogą zakładać - realizując swoje cele statutowe - także inne jednostki organizacyjne nie wykluczając osób prawnych. Jedną z takich osób są spółdzielnie socjalne, które mogą pomagać osobom ubogim nie tylko poprzez typowe przekazywanie pomocy materialnej i niematerialnej, ale co charakterystyczne, włączając takie osoby w działalność spółdzielczą, jednocześnie ich aktywizują. W ten sposób takim osobom zależy na dbaniu o rozwój spółdzielni, którą przecież współtworzą bezpośrednio swoim działaniem. Wydaje się, że taka pomoc w istotnym stopniu przywraca osobom zagrożonym wykluczeniem poczucie własnej godności.

W tym miejscu można wstępnie przyjąć, że założenie spółdzielni socjalnej jest indywidualnym uprawnieniem kościelnych osób prawnych mającym umocowanie w normach wyższego rzędu, co pozwala w odpowiednim

Dr Micha£ Poniatowski - Katedra Prawa Wyznaniowego i Komparatystyki Prawniczej, Wydział Prawa Kanonicznego, Uniwersytet Kardynała Stefana Wyszyńskiego w Warszawie; adres do korespondencji: ul. Dewajtis 5, 01-815 Warszawa, Polska; e-mail: michal.poniatowski@adwokatura.pl; https://orcid.org/0000-0002-7263-4550 
zakresie nadać brzmienie statutu mając na uwadze specyfikę działalności charytatywnej prowadzonej przez takiego założyciela.

Ze względu na ramy niniejszego artykułu przedmiotowe zagadnienie zostanie przedstawione w zakresie polskiego porządku prawnego.

\section{ZARYS HISTORYCZNY DZIAŁALNOŚCI CHARYTATYWNEJ I SPÓŁDZIELCZEJ}

W Polsce działalność charytatywna kościelnych osób prawnych trwa od wieków. Warto w tym miejscu nadmienić, że w przypadku Kościoła katolickiego tego typu działalność można zauważyć już od początku Jego istnienia. W I Rzeczypospolitej to kościelne osoby prawne wiodły prym w prowadzeniu działalności charytatywnej m.in. tworząc różnego rodzaju formy prowadzenia działalności charytatywnej, jak przytułki czy domy dla sierot. Co istotne w okresie rozbiorów tego typu działalność była jednym z łączników między Polakami mieszkającymi w różnych zaborach. W II Rzeczypospolitej nastąpił istotny rozwój instytucjonalny tego typu działalności, co obrazuje chociażby erygowanie licznych jednostek organizacyjnych Caritas. Okres Polski Ludowej to $\mathrm{z}$ kolei okres degradacji tego typu działalności, a nawet niejednokrotnie jej delegalizacja. Dopiero odzyskanie suwerenności po 1989 r. pozwoliło na przywrócenie wolności w zakresie prowadzenia działalności charytatywnej przez kościelne osoby prawne.

Działalność spółdzielcza, choć ma krótszą historię, to nie stanowi novum, albowiem taka działalność była charakterystyczna już w XIX w. Polacy tworząc różnego rodzaju wspólnoty spółdzielcze również przyczynili się do zachowania swojej tożsamości. Co istotne zarówno działalność charytatywna, jak i spółdzielcza nie były od siebie odizolowane. Niejednokrotnie dochodziło do współdziałania kościelnych osób prawnych i spółdzielczych jednostek organizacyjnych. Okres komunizmu zakłócił tego typu naturalne współdziałanie, przy czym choć sama działalność spółdzielcza nie była w tym okresie generalnie zakazana. Upadek tego ustroju pozwolił nie tylko na przywrócenie możliwości podjęcia tego typu współdziałania, ale aktualnie nawet na założenie spółdzielni socjalnej przez kościelne osoby prawne, co zostało zagwarantowane w ustawie z dnia 27 kwietnia 2006 r. 
o spółdzielniach socjalnych ${ }^{1}$. Ratio legis tej ustawy sprowadza się do walki $\mathrm{z}$ wykluczeniem społecznym ${ }^{2}$. Podobny cel realizują tradycyjnie również kościelne osoby prawne w ramach działalności charytatywnej.

Mając powyższe na uwadze można dojść do wniosku, że działalność charytatywna kościelnych osób prawnych i działalność spółdzielcza, choć mają swoją własną historię, to nie oznacza to, że są od siebie odizolowane. $\mathrm{Z}$ uwagi na nakładające się niektóre cele tych działalności, jak troska o dobro wspólne i dobro człowieka, niejednokrotnie wywierają na siebie wpływ nie wykluczając sfery prawnej, co obrazuje chociażby możliwość współdziałania kościelnych osób prawnych ze spółdzielczymi jednostkami organizacyjnymi w ramach realizacji powyższych celów, czy też przedmiotowe zakładanie przez kościelne osoby prawne spółdzielni socjalnych, które są dosyć nową formą działalności spółdzielczej w Polsce.

\section{SPÓŁDZIELNIA SOCJALNA W ROZUMIENIU PRAWA POLSKIEGO}

Ustawa o spótdzielniach socjalnych określa zasady zakładania, prowadzenia działalności, łączenia jak również likwidacji spółdzielni socjalnej (art. 1 ust. 1 u.s.s.). Przy czym należy pamiętać, że ustawa ta nie ma charakteru kompleksowego (art. 1 ust. 2 u.s.s.) ${ }^{3}$. Nie zawiera ona m.in. definicji legalnej spółdzielni socjalnej ${ }^{4}$ Definicję legalną samego pojęcia spół-

\footnotetext{
${ }^{1}$ Dz. U. z 2020 r., poz. 2085 z późn. zm. [dalej: u.s.s.].

${ }^{2}$ Por. Druk nr 49 z dnia 19 października 2005 r., Sejm V kadencji (uzasadnienie rządowego projektu ustawy o spółdzielniach socjalnych). W uzasadnieniu wskazano: „Celem wprowadzanej ustawy jest przywrócenie na rynek pracy, przez prowadzenie wspólnego przedsiębiorstwa osób zagrożonych wykluczeniem społecznym, osób o niskiej zatrudnialności oraz umożliwienie osobom bezrobotnym aktywizację zawodową. [...] Ustawa wspiera istniejący system zatrudnienia socjalnego, stwarzając nowe możliwości znalezienia pracy i powrotu na rynek pracy dla osób zagrożonych wykluczeniem społecznym oraz zaliczanych do osób o tzw. niskiej zatrudnialności. Realizuje zasadę «praca zamiast zasiłku», wprowadzając skuteczny mechanizm aktywizacji zawodowej oraz reintegracji zawodowej dla tych, którzy są zagrożeni wykluczeniem z rynku pracy”.

${ }^{3} \mathrm{~W}$ sprawach $\mathrm{w}$ niej nieuregulowanych stosuje się przepisy ustawy z dnia 16 września 1982 r. Prawo spótdzielcze, Dz. U. z 2021 r., poz. 648 z późn. zm. [dalej: u.p.s.].

${ }^{4}$ Warto jednak zwrócić uwagę na definicję spółdzielni wskazaną we wspomnianym uzasadnieniu projektu ustawy: „Międzynarodowy Związek Spółdzielczy definiuje spółdzielnię jako: autonomiczne stowarzyszenie osób dobrowolnie zjednoczonych w celu zaspokojenia swoich wspólnych potrzeb oraz aspiracji gospodarczych, społecznych i kul-
} 
dzielni zawarto jednak w ustawie Prawo spółdzielcze, do której odsyła ustawa o spółdzielniach socjalnych: „Spółdzielnia jest dobrowolnym zrzeszeniem nieograniczonej liczby osób, o zmiennym składzie osobowym i zmiennym funduszu udziałowym, które w interesie swoich członków prowadzi wspólną działalność gospodarczą" (art. $1 \S 1$ u.p.s.) $)^{5}$. Charakterystyczne dla spółdzielni socjalnej jest to, że działa ona na rzecz społecznej lub zawodowej reintegracji jej członków oraz pracowników spółdzielni socjalnych, będących osobami, o którym mowa w art. 4 ust. 1 u.s.s. (art. 2 ust. 2 u.s.s.), zaś działania te nie są wykonywane w ramach prowadzonej przez spółdzielnię socjalną działalności gospodarczej. Takie uregulowania dążą do realizacji wspomnianego w uzasadnieniu projektu tej ustawy modelu spółdzielczości socjalnej, który „,...] realizuje cele walki z wykluczeniem społecznym”. Ponadto spółdzielnia taka może: „[...] prowadzić działalność społeczną i oświatowo-kulturalną na rzecz swoich członków, pracowników oraz ich środowiska lokalnego [...]" (art. 2 ust. 3 u.s.s.). Spółdzielnia socjalna może również prowadzić bardzo szeroką pod względem przedmiotowym działalność społecznie użyteczną w sferze zadań publicznych, które są określone w art. 4 ust. 1 ustawy z dnia 24 kwietnia 2003 r. o działalności pożytku publicznego i o wolontariacie . $^{\text {. }}$

W konsekwencji dążenia do realizacji tych działań spółdzielnia socjalna korzysta z szeregu rodzaju zwolnień ${ }^{7}$ i źródeł finansowania ${ }^{8}$, które wzmacniają rozwój spółdzielczości socjalnej. Tego typu uregulowania są uzasadnione właśnie charakterem działalności i istotą spółdzielni socjalnych.

W zakresie zagadnień o charakterze formalnym należy ogólnie wskazać, że spółdzielnie socjalne mają osobowość prawną, którą uzyskują z chwi-

turalnych przez stanowiące wspólną własność i demokratycznie kontrolowane przedsiębiorstwo". W literaturze podkreśla się wspólną aksjologię międzynarodowego ruchu spółdzielczości [Ziobrowska 2016, 334].

${ }^{5} \mathrm{Na}$ marginesie warto zwrócić uwagę na różnicę jednostek redakcyjnych poszczególnych artykułów w tych dwóch ustawach zbliżonych przecież pod względem przedmiotowym.

${ }^{6}$ Dz. U. z 2020 r., poz. 1057 z późn. zm. [dalej: u.d.p.p.w.]. Spółdzielnie socjalne mogą zatem prowadzić działalność w sferze określonych zadań publicznych.

${ }^{7}$ Przykładowo zwolnienia ze składek określonych w art. 266 u.p.s. (por. art. 17a u.s.s.). Innym przykładem jest zwolnione z opłaty sądowej wniosku o wpis (por. art. 6 ust. 3 u.s.s.).

${ }^{8}$ Przykładowo możliwość otrzymywania dotacji ze środków budżetu państwa lub środków budżetu jednostki samorządu terytorialnego (por. art. 15 ust. 1 pkt 1 u.s.s.) [Michalik 2015, 104-54]. 
lą wpisu do Krajowego Rejestru Sądowego (art. $11 \S 1$ u.p.s.). Wniosek o wpis spółdzielni do rejestru na odpowiednim formularzu składa wybrany zarząd dołączając m.in. przyjęty statut, który zostanie przedstawiony w dalszej części artykułu.

Wobec powyższego można dojść do wniosku, że istotą funkcjonowania spółdzielni socjalnych $\mathrm{w}$ polskim porządku prawnym jest walka $\mathrm{z}$ wykluczeniem społecznym określonych kategorii osób poprzez umożliwienie im osobistej pracy (w myśl wspomnianej zasady „praca zamiast zasiłku”). Zatrudnianie tej kategorii osób niesie ze sobą możliwość instytucjonalnego wspierania działalności spółdzielni socjalnych ze środków budżetu państwa lub środków budżetu jednostki samorządu terytorialnego pomimo tego, że prowadzą one także działalność gospodarczą ${ }^{9}$.

\section{UPRAWNIENIE KOŚCIELNYCH OSÓB PRAWNYCH DO ZAŁOŻENIA SPÓŁDZIELNI SOCJALNYCH}

Spółdzielnie socjalne mogą być zakładane samodzielnie - poza osobami fizycznymi spełniającymi ściśle określone ustawowe przesłanki (art. 4 ust. 1 2 pkt 1 u.s.s.), czy organizacjami pozarządowymi (art. 4 ust. 2 pkt 2 u.s.s.) - przez co najmniej dwie kościelne osoby prawne (art. 4 ust. 2 pkt 3 u.s.s. w zw. $\mathrm{z}$ art. 5 ust. 1 u.s.s.). Takie uprawnienie odpowiada zasadzie równości wobec innych osób prawnych będących organizacjami pozarządowymi ${ }^{10}$. Warto jednocześnie zaznaczyć nadal aktualną problematykę pojęcia organizacji pozarządowych, które w polskim systemie prawnym czasami zawierają w sobie kościelne osoby prawne ${ }^{11}$, a czasami nie (art. 3 ust. 2 u.d.p.p.w.).

\footnotetext{
${ }^{9}$ Jednocześnie należy zauważyć, że zarówno w przypadku spółdzielni socjalnych, jak także w przypadku innych osób prawnych prowadzenie działalności gospodarczej może odbywać się równolegle do prowadzonej działalności pożytku publicznego. Por. także art. 5 ust. 5 ustawy z dnia 6 kwietnia 1984 r. o fundacjach, Dz. U. z 2020, poz. 2167 [Dominowska 2017; Kocowski 2019, 311-21].

10 Dodatkowo warto zwrócić uwagę, że zgodnie z art. 22 ust. 1 Konkordatu między Stolicą Apostolską i Rzecząpospolitą Polską z dnia 28 lipca 1993 r. (Dz. U. z 1998 r., Nr 51, poz. 318), „Działalność służąca celom humanitarnym, charytatywno-opiekuńczym, naukowym i oświatowo-wychowawczym, podejmowana przez kościelne osoby prawne, jest zrównana pod względem prawnym z działalnością służącą analogicznym celom i prowadzoną przez instytucje państwowe".

${ }^{11}$ Por. art. 2 pkt 2 ustawy z dnia 19 lipca 2019 r. o przeciwdziałaniu marnowania żywności, Dz. U. z 2020 r., poz. 1645.
} 
Gdyby kościelne osoby prawne nie były wymienione explicite w tym przepisie obok organizacji pozarządowych, to i tak na podstawie wykładni systemowej i funkcjonalnej należałoby dojść do wniosku, że kościelne osoby prawne nie powinny być traktowane odmiennie od organizacji pozarządowych sensu stricte. Jednocześnie należy zauważyć, że przed wejściem w życie ustawy o spółdzielniach socjalnych zarówno organizacje pozarządowe, jak i kościelne osoby prawne nie były wymienione wśród podmiotów, które mogły założyć spółdzielnię socjalną (por. art. 203a u.p.s.) ${ }^{12}$. Taką możliwość miały ściśle określone osoby fizyczne zagrożone wykluczeniem społecznym. Należy zatem z aprobatą odnieść się do rozszerzenia katalogu podmiotów posiadających uprawnienie do założenia spółdzielni socjalnych równocześnie o organizacje pozarządowe i kościelne osoby prawne, co jest przykładem na ich równe traktowanie. Ponadto taka zmiana ma istotne znaczenie dla wykładni historycznej. Ewentualne wątpliwości interpretacyjne należy wstępnie rozstrzygać rozszerzająco $\mathrm{w}$ kierunku rozszerzenia prawa kościelnych osób prawnych do zakładania spółdzielni socjalnych. Co istotne spółdzielnie socjalne mogą być zakładane przez co najmniej dwie osoby prawne, a zatem możliwe jest założenie spółdzielni socjalnej np. przez jedną organizację pozarządową i kilka kościelnych osób prawnych, itp.

Ponadto uprawnienie do zakładania spółdzielni socjalnych stanowi pośrednio rozwinięcie uprawnienia, o którym mowa w art. 24 ustawy z dnia 17 maja 1989 r. o gwarancjach wolności sumienia $i$ wyznania ${ }^{13}$, zgodnie z którym: „W celu realizacji działalności charytatywno-opiekuńczej kościoły i inne związki wyznaniowe mają prawo zakładać i prowadzić, na zasadach określonych w ustawach, odpowiednie instytucje, w tym zakłady dla osób potrzebujących opieki, szpitale i inne zakłady lecznicze podmiotów leczniczych w rozumieniu przepisów o działalności leczniczej, żłobki i schroniska dla dzieci". Ustawa ta ma charakter uniwersalny i ma zastosowanie odpowiednio do wielu osób prawnych poszczególnych związków wyznaniowych, które prowadzą tego typu działalność.

Uprawnienie kościelnych osób prawnych nie stanowi zatem jakiegokolwiek przywileju. Takie uprawnienie należy uznać za uszczegółowienie konstytucyjnej i międzynarodowej zasady poszanowania autonomii i niezależności Kościoła i państwa każdego w swoim zakresie oraz zasady

\footnotetext{
12 Przepis ten po raz pierwszy regulował kwestię funkcjonowania spółdzielni socjalnych [Jedlińska 2020, 795].

${ }^{13}$ Dz. U. z 2017 r., poz. 1153.
} 
współdziałania dla dobra wspólnego i dobra człowieka ${ }^{14}$. Jednocześnie należy pamiętać, że niejednokrotnie może okazać się konieczne przeanalizowanie prawa poszczególnych związków wyznaniowych w kontekście ważności oświadczenia woli w zakresie założenia spółdzielni socjalnej. Przykładowo w Kościele katolickim w przypadku założenia spółdzielni socjalnej, której miałby zostać przekazany majątek przekraczający odpowiednie limity kwotowe konieczne jest uzyskanie zgód określonych w normach dotyczących alienacji, np. Konferencji Episkopatu Polski lub dodatkowo Stolicy Apostolskiej.

Powyższe uprawnienie kościelnych osób prawnych wpisuje się z jednej strony w uznanie prowadzenia działalności charytatywnej przez kościelne osoby prawne, a z drugiej strony wspomaga rozwój spółdzielczości. Nie bez znaczenia jest przecież doświadczenie, majątek i struktura kościelnych osób prawnych dla rozpoczęcia działalności przez spółdzielnię socjalną, a następnie jej wspieranie i ukierunkowywanie. Mając na uwadze polski porządek prawny uprawnienie to jest ustawowym uszczegółowieniem wspomnianych norm wyższego rzędu.

\section{STATUT SPÓŁDZIELNI SOCJALNYCH ZAKŁADANYCH PRZEZ KOŚCIELNE OSOBY PRAWNE}

Skoro kościelne osoby prawne posiadają explicite uprawnienie do zakładania spółdzielni socjalnych, to pojawia się pytanie, czy mogą one sformułować statut spółdzielni socjalnej mając na uwadze swoją specyfikę działalności charytatywno-opiekuńczej?

Sama ustawa o spótdzielniach socjalnych nie zawiera katalogu elementów statutu spółdzielni socjalnej i odnosi się do jego treści jedynie częściowo ${ }^{15}$. W związku z tym należy odnieść się do art. $5 \S 1$ u.p.s., który zawiera taki katalog obligatoryjnych elementów statutu. Z drugiej strony należy wskazać, że $\S 2$ tego artykułu pozwala na zawarcie w statucie postanowień o charakterze fakultatywnym. W przypadku postanowień o charakterze

${ }^{14}$ Por. art. 25 Konstytucji Rzeczypospolitej Polskiej z dnia 2 kwietnia 1997 r., Dz. U. Nr 78, poz. 483; zob. także art. 1 Konkordatu.

${ }^{15}$ Przykładowo zgodnie $\mathrm{z}$ art. 7 ust. 2 u.s.s. statut spółdzielni socjalnej może stanowić, że wybiera się radę nadzorczą, nawet wtedy, gdy liczba członków tej spółdzielni nie przekracza piętnastu. 
obligatoryjnym kościelne osoby prawne mogą je odpowiednio modyfikować, jednakże takie zmiany nie mogą być sprzeczne $\mathrm{z}$ treścią ustawy, np. zakazane byłoby wprowadzenie zakazu uzyskiwania członkostwa w spółdzielni socjalnej przez zatrudnionych w niej pracowników, o których mowa w art. 4 ust. 1 u.s.s. (art. 5a ust. 2 u.s.s. w zw. z art. $5 \S 1$ pkt 5 u.p.s.), czy też określenie przedmiotu działalności spółdzielni socjalnej wbrew treści art. 2 u.s.s. Takie ramy prawne dotyczą również postanowień statutu spółdzielni socjalnej o charakterze fakultatywnym. Wydaje się jednak, że przykładowo wprowadzenie kodeksu etyki pracowników jako załącznika do statutu, możliwości współdziałania z podmiotami prowadzącymi działalność charytatywną, czy też określenie limitu kosztów prowadzonej działalności nie stanowiłoby naruszenia swobody kościelnej osoby prawnej jako założyciela spółdzielni socjalnej.

Wobec powyższego należy stwierdzić, że przyjęcie konkretnego brzmienia statutu należy do decyzji kościelnych osób prawnych zakładających spółdzielnię socjalną, przy czym nie można naruszyć poprzez taki statut istoty spółdzielni socjalnej, jak i szerzej przepisów prawa spółdzielczego o charakterze ius cogens. Specyfika kościelnej osoby prawnej jako założyciela spółdzielni socjalnej $\mathrm{w}$ tak wyznaczonych ramach może znaleźć odzwierciedlenie $\mathrm{w}$ dwojakich postanowieniach statutu, tj. postanowieniach o charakterze obligatoryjnym lub fakultatywnym.

\section{WNIOSKI}

Zakładanie spółdzielni socjalnej przez kościelne osoby prawne wpisuje się w zakres działalności charytatywnej i służy walce z wykluczeniem społecznym. Tego typu spółdzielnie, dając możliwość podjęcia pracy osobom wykluczonym, przywracają im pewność siebie, poczucie wartości swojej pracy i stopniowo odsuwają te osoby od konieczności zapewnienia im pomocy społecznej. Niejednokrotnie w funkcjonujących spółdzielniach socjalnych dochodzi do synergii działalności charytatywnej i działalności spółdzielczej.

Jednocześnie powyższe prawo kościelnych osób prawnych można uznać za przykład uszczegółowienia konstytucyjnej i międzynarodowej zasady poszanowania autonomii i niezależności Kościoła i państwa każdego w swoim zakresie oraz zasady współdziałania tych podmiotów na rzecz dobra 
wspólnego i dobra człowieka. W konsekwencji kościelne osoby prawne w odpowiednim zakresie mogą nadawać brzmienie statutu spółdzielni socjalnych, jednakże z zachowaniem istoty tych spółdzielni, jak i szerzej przepisów prawa spółdzielczego o charakterze ius cogens. Sama realizacja prawa kościelnych osób prawnych do zakładania spółdzielni socjalnych wymaga analizy zarówno prawa powszechnego, ale także prawa wewnętrznego poszczególnych związków wyznaniowych.

\section{PIŚMIENNICTWO}

Dominowska, Joanna. 2017. Prowadzenie działalności gospodarczej przez fundacje. Studium prawne. Warszawa: Wolters Kluwer Polska.

Jedlińska, Martyna. 2020. „Spółdzielnie socjalne.” W System prawa prywatnego. T. 21: Prawo spótdzielcze, red. Krzysztof Pietrzykowski, 794-822. Warszawa: Wydawnictwo C.H. Beck.

Kocowski, Tadeusz. 2019. „Spółdzielnia socjalna jako przedsiębiorca wykonujący działalność społecznie użyteczną." Acta Universitatis Wratislaviensis. Prawo t. 329, 311-21.

Michalik, Andrzej. 2015. Status prawny spótdzielni socjalnych $w$ prawie polskim. Elbląg: Wydawnictwo Państwowej Wyższej Szkoły Zawodowej w Elblągu.

Ziobrowska, Justyna. 2016. „Spółdzielnie socjalne jako przykład rozwoju przedsiębiorczości społecznej w Polsce.” Studia i Prace WNEIZ US 46, nr 2:333-42.

\section{Zakładanie spółdzielni socjalnych przez kościelne osoby prawne}

Abstrakt

W przedmiotowym artykule zostało przedstawione zagadnienie zakładania spółdzielni socjalnych przez kościelne osoby prawne. W pierwszej kolejności został scharakteryzowany zarys historyczny działalności charytatywnej i działalności spółdzielczej, a następnie zagadnienie pojęcia spółdzielni socjalnej w rozumieniu prawa polskiego. W dalszej kolejności przedstawiono podstawy prawa kościelnych osób prawnych do założenia spółdzielni socjalnych oraz specyfikę statutu takich spółdzielni. Ostatnia część artykułu zawiera wnioski końcowe.

Słowa kluczowe: spółdzielnia socjalna; kościelna osoba prawna; działalność charytatywna; osoby ubogie; godność 


\title{
Establishing Social Cooperatives by Church Legal Entities
}

\begin{abstract}
The article presents the issues of establishing social cooperatives by church legal entities. First, a historical outline of charity and cooperative activities is presented, and then the issue of the definition of a social cooperative in accordance with Polish law. Then, the legal basis for the rights of church legal persons to establish social cooperatives and the specificity of the statute of these cooperatives are presented. The final conclusions are presented in the last part of the article.

Keywords: social cooperative; church legal person; charity; poor people; human dignity

Information about Author: DR. MiChAє PoniATOWSKI - Department of Religious Law and Comparative Legal Studies, Faculty of Canon Law, The Cardinal Stefan Wyszyński University in Warsaw; correspondence address: ul. Dewajtis 5, 01-815 Warszawa, Poland; e-mail: michal.poniatowski@adwokatura.pl; https://orcid.org/ 0000-0002-7263-4550
\end{abstract}

